\title{
Find the future from the past: Paleolimnology in Indonesia
}

\author{
Tri Retnaningsih Soeprobowati ${ }^{1,2}$, Sri Widodo Agung Suedy ${ }^{12}$, Hadiyanto ${ }^{1,3}$ \\ ${ }^{1}$ School of Postgraduate Studies, Diponegoro University, Semarang Indonesia \\ ${ }^{2}$ Department of Biology, Faculty of Science and Mathematics, Diponegoro University, Semarang Indonesia \\ ${ }^{3}$ Department of Chemical Engineering, Faculty of Engineering, Diponegoro University, Semarang Indonesia
}

\begin{abstract}
Agriculture, hydro electricity power, fisheries, source of drinking water, recreation, and industrial use has led to wide-spread impairment of Indonesia surface waters. Indonesia is rich with various freshwaters, including 840 unique lakes with different size and types, 735 ponds, and 162 dams that covering about $21,000 \mathrm{~km}^{2}$ of area, contain about $500 \mathrm{~km}^{3}$ of water functions as both economically and ecologically purposes. Indonesia is also one of the biggest listed freshwater endemic species in Asia. However, an increase of population and human activities affect a decrease in quantity and quality of several lake ecosystems that able to induce the destruction up to extinction of the lake ecosystem. An increase of lake utilization, with partial management system without considering the preservation and sustainability of ecosystem had reduced lake functions. Paleolimnological approach is one of science and technological approach to support the successfull of grand design of Indonesian lakes conservation and rehabilitation, specifically on the program of lakes' development ecosystem monitoring, evaluation, and information system. The studied on (paleo) limnology in Indonesia had been collected and compared. The vertical distribution of trace elements of $\mathrm{Ni}, \mathrm{Mg}$, and $\mathrm{B}$ were analyzed by Inductively Coupled Plasma (ICP) with mass spectrophotometry for $44 \mathrm{~cm}$ sediment core from Telaga Pengilon Dieng, Java. The paleolimnological studies in Indonesia have been limited, particularly for Indonesian as the first author. Lakes'sediment records the changes condition of catchment area, like a diary book. Reconstruction of the past environmental condition is required to predict the future condition. This can be done using the organism preserved in the sediment, such as diatoms and pollen. Diatoms are unicellular algae that are used extensively in paleoecology. The diatom assemblages in sedimentary records can make direct and indirect inferences about past environmental conditions. The palynological data on the terrestrial and aquatic ecosystem are used as an indicator of recent and paleoecological changes, particularly on the climate, history and floral diversity. Paleolimnological analysis increasingly attention is being given to developing the technique to model human activities.
\end{abstract}

\section{Introduction}

Indonesia own more than 840 lakes by which 521 are having more than 10 hectares wide that spread out in Sumatra, Kalimantan, Papua, Java and Bali, Sulawesi, NTT and NTB, and Maluku. Indonesia also has 735 ponds, 162 dams that totally covering about $21,000 \mathrm{~km}^{2}$ of area and resettling about $500 \mathrm{~km}^{3}$ water volume. In Indonesia, lakes and reservoirs are important water resources, mainly for water supply and irrigation, while the remaining serves as storage basin for agricultural usage, hydroelectricity power, flood control, recreational activities, fisheries, uniqueness of tradition, culture and heritage, habitat for high diversity of potentially endemic, rare, and endangered species of flora and fauna [1].

At present, lake degradation has progressed at an accelerating rate due to changes in land use pattern, resulting in the deterioration lakes' function and services. The development of lake management strategies have to consider long term changes and dynamics and its variability. Sediment core from the lake is a diary book that tells the story about what happen in the catchment area. Indonesia rich with the type and variety lakes that mostly utilized only for water resources with sectorial management, based on their own interests that in turn induce conflict of interest.

As endorses at the National Conference of Indonesian Lake II commenced on 13-14 October 2011 in Semarang, the Ministry of Environment restated that the 15 lakes are nationally treasured as the priority of environmental crisis to be resolved following Bali Agreement on Sustainable Management of Lake on 13 August 2009. At the first phase (2010-2014) 15 lakes priority were Lake Toba, Maninjau, Singkarak, Kerinci, Tondano, Limboto, Poso, Tempe, Matano, Kaskade

\footnotetext{
Corresponding author: trsoeprobowati@live.undip.ac.id
} 
Mahakam Semayang-Melintang-Jempang, Sentarum, Sentani, Rawa Danau, Batur, and Rawapening. The second phases (2015-2019) there are consideration for another 15 lakes, i.e Lake Diatas, Dibawah, Ranau, Dendam Tak Sudah, Lindu, Towuti, Mahalona, Bratan, Paniai, Laut Tawar, Aneuk Laot, Kelimutu, Rinjani, Taliwang, and Tasik.

It is certainly a challange task to do paleolimnological research as a basic for developing suitable lake management. Save Indonesia Lake References book were developed for each lake, basically with 3: approaches science and technology application for remediate water and catchment area, governance, and community involvement for lake conservation. One of super prirority program that have to be considered in Save Indonesia Lakes was paleolimnological studies [2]. One of recommendation from 16th World Lake Conference, November 2016 was that paleolimnology can play valuable roles in addressing many lake issues including risk management and disaster preparedness.

Paleolimnology was freshwater studies focused on the intepretation of sequent sediments and diagenetic process that influenced the sedimentary record. The aims of paleolimnology were to figure out the past condition, productivities, and changes of parameters than induce changes of lakes productivity [3]. Paleolimnology is the study on the interrelation watershed geology, watershed climate, mode of Lake formation/evolution, inflow/outflow hydrology, internal circulation, and organic productivity, which were ultimately linked to regional climate, geology, and human activities [4]. Paleolimnology is multidiscipline approach of using physical, chemical, and biological informations from sediment to reconstruct past environmental condition, particularly for freshwater ecosystem. Paleolimnology is study about long-term changes on geomorphological lakes [5]. Paleolimnology has been used for decades to reconstruct past environments and more recently help the scientist to understanding and observed changes that occurred in the past [6]. Paleolimnology also provide knowledge about environmental process in ancient time and useful to determine geochemistry mechanism in lake [7]. Therefore, paleolimnology is basically learn about stratigraphy sediment of the lakes where fossils well preserved in the sediment and provides information about past condition of the catchment area. However, paleolimnological studies in Indonesia was very limited [8].

\section{Methods}

This research is combination qualitative and quantitative methods. Qualitatively, data collection for research on paleolimnology in Indonesia was done through searching in Research Center for Limnology Indonesia, communicate with Society of Indonesian Limnology, and searching in internet. The result was listed in the table and several stratigraphy of pollen and diatoms were selected and compare. Quantitatively, this paper provides stratigraphy of heavy metals Nickel (Ni), Magnesium (Mg), and Boron (B) from Telaga Pengilon Dieng. Sediment cores were collected from 3 sites of Telaga Pengilon using modified core barrel. After retrieval the cores were maintain in vertical orientation. Slicing sediment core was every $1 \mathrm{~cm}$ using plastic spatula and ruler. Sediment were placed in plastic zip lock and store at $4^{\circ} \mathrm{C}$. In this study, only 1 core has been analyzed down to $44 \mathrm{~cm}$ to provide $\mathrm{Ni}, \mathrm{Mg}$, and $\mathrm{B}$ from Telaga Pengilon. A manuscript incorporating long term history of catchment area of these lakes based on diatoms were being produced and will be published elsewhere. Analysis of heavy metals was conducted in Western Carolina University US using Inductively Coupled Plasma (ICP) with mass spectrophotometry. The data of $\mathrm{Ni}, \mathrm{Mg}$ and $\mathrm{B}$ were $\log 10$ transformed and graphed using the software package $\mathrm{C} 2$ version 1.7.7 [9].

\section{Result and Discussion}

Based on the tracer study, at least 30 research on limnology in Indonesia had been recorded since Sunda Limnological Expedition organized by Ruttner in between September 1928 and July 1929 (Table 1). This expedition emphesize to study the biology of numerous lakes, ponds, swamps, paddies fields and other aquatic ecosystem in Sumatra, Java, and Bali [10]. The diary, stereoscopic photographs, and all scientific data of Ruttner and Thienemann provided the basis for tropical limnology. Limnology has shown its capacity to provide the very basis for a cautious and environment oriented development. For the commemoration of the 65 anniversary of the Ruttner-Thienemann Sunda Limnological Expedition, the International Conference on Tropical Limnology was held on 4-8 July 1994 at the Christian University of Satya Wacana Salatiga, Central Java, Indonesia that was attended by experts from various countries and wide spectrum of topic. The proceeding entitle Tropical Limnology was the valuable document that consist of 3 volume. Volume I Present Status and Challanges, volume II Tropical Lakes and Reservoirs, and volume III Tropical Rivers, Wetlands and Specials Topics [10].

The other important note of Expedition Indodanau was initiated in 1991 by the Research Institute for Water Resource Development, affiliated to the Agency for Research and Development of the Indonesian Ministry of Public Works, in cooperation with Finnish counterpart. Expedition Indodanau dealed with physical, chemical, and biological characteristics of 38 lakes and reservoirs situated in Sumatra, Java, Bali, Lombok, Flores, Sulawesi, and Irian Jaya. Expedition Indodanau provide information and database on physical, chemical, phytoplanton variables for contemporary evaluation and comparison, and as basis for longterm monitoring programs [11]. Now, the data 
from those expedition became the baseline for paleolimnological analysis. The newest expediton was in Towuti Lake Sulawesi, 1 out of 3 lake known as
Malili Lakes (Matano, Mahalona and Towuti Lakes) the highest publication as one of ancient lake in the world.

Table 1. Research on paleolimnology of Indonesian lake

\begin{tabular}{|c|c|c|c|}
\hline No & Island & Lake & Source \\
\hline 1 & Sulawesi & Towuti & $\begin{array}{l}{[11],[12],[41],} \\
{[13],[14],[15]}\end{array}$ \\
\hline 2 & Papua & Kutubu & {$[39],[40]$} \\
\hline 3 & Sumatra & Singkarak Toba & {$[26],[43],[30]$} \\
\hline 4 & Sumatra & Aceh & {$[27]$} \\
\hline 5 & Java & Logung & {$[22]$} \\
\hline 6 & Java & Rawapening & {$[23]$} \\
\hline 7 & Java & Pekalongan, Brebes, Semarang, Demak, Rembang & {$[24]$} \\
\hline 8 & Kalimantan, Papua & Berau, Raja Ampat & {$[42]$} \\
\hline 9 & Sulawesi & Matano & {$[16][17][18][19]$} \\
\hline 10 & Sulawesi & Wakatobi & {$[20]$} \\
\hline 11 & Kalimantan & Batulicin & {$[33]$} \\
\hline 12 & Sulawesi & Tondano & {$[21]$} \\
\hline 13 & Java & Borobudur & {$[25]$} \\
\hline 14 & Java & Dieng & {$[32]$} \\
\hline 15 & Sumatra & Banda & {$[29]$} \\
\hline 16 & Sumatra & $\begin{array}{l}\text { Laut Tawar,Toba, Maninjau, Diatas, Dibawah, } \\
\text { Singkarak, Kerinci, Ranau, }\end{array}$ & {$[11]$} \\
\hline 17 & Java & $\begin{array}{l}\text { Saguling (R), Cirata (R), Jatiluhur (R), Darma (R), } \\
\text { Sempor (R), Mrica (R), Rawapening, Gadjah } \\
\text { Mungkur (R), Kedung Ombo (R), Sengguruh (R), } \\
\text { Lahor (R), Sutami (R), Wlingi (R), Selorejo (R) }\end{array}$ & {$[11]$} \\
\hline 18 & Flores & Kelimutu & {$[44]$} \\
\hline 19 & Halmahera & Island & {$[28]$} \\
\hline 20 & Sumatra & Padang & [31] \\
\hline
\end{tabular}

At least 12 publications on the lakes in Sulawesi, such as by Goudge et al,[11]; Morlock et al, [12]; Costa et al, [13], Russell et al, [14]; Russell \& Bijaksana, [15]; Jones et al, [16]; Vailant et al, [17]; Tamuntuan et al, [18]; Crowe et al, [19]; Engelhart et al, [20], Dama et al, [21], and Lehmusluoto et al, [11]. At least 6 publications related to the paleolimnology in Java ([22], [23]; [24]; [25], [11], and [10]). In Sumatra there were at least 8 researchs on paleolimnology, which were by Setyobudi et al, [26]; Grand et al, [27]; van der Kaars et al, [28]; van der Kaars et al, [29]; Lehmusluoto et al, [11]; Nishimura et al, [30]; Morley, [31]; and Ruttner, [10]. There were also research on paleolimnology in Papua, Kalimantan, Flores, and Halmahera (Table 1). Most of those publications were the output of project with the international funding. There is still limited publication on the paleolimnlogy with the first author is Indonesian. Pudjoarinto [32] studied about pollen stratigraphic as an human activity evidence in Dieng. But that was his last research before pass away. Yulianto [33] followed research on holocene pollen. Soeprobowati et al ([23],[24]) initiated to study on diatoms for paleolimnlogical tool for reconstruction past environmental changes. Setyobudi et al [26] focused on the sedimentology and limnology.
Tamuntuan [18] studied the magnetic properties of tectonic lake sediment. Bijaksana was Indonesian geologist that have many publications related to the Towuti project.

The research that purely studied on paleolimnology in Indonesia that were used biological tools of pollen and diatoms were in Telaga Balekambang Dieng [32], Lake Tondano [21], and Lake Rawapening [23]. Pudjoarinto \& Cushing [32] found that pollen preserved in Telaga Balekambang Dieng indicated pattern of vegetation in the catchment area. There were 5 zones that indicated human settlement and cultivation. The dominance of Plantago major indicated that Hindu-Javanese religious was centered in Dieng since $700 \mathrm{BP}$. Land changes from montane forest into agriculture was indicated by a decrease of trees and an increase of cultivated plants that was started in Dieng since 1920 (Figure 1).

Based on the pollen preserved in the sediment, in 33,000 until 30,840 yr BP indicated low land - sub montane forest around Lake Tondano. A high diverse of non-diatoms indicated lacustrine deep water. The dominance of epiphytic diatoms species of Cocconeis placentula, Epithemia adnata, and planktonic species of Aulacoseira granulata indicated that Lake Tondano was 
deep eutrophic lake that have abundant of submerge plants. The dominance of small diatoms of Fragillaria spp and $A$. granulata indicated that in 33,000 yr BP was full lacustrine, open shallower water. An absent of $A$. granulata in $30,840 \mathrm{yr} \mathrm{BP}$ indicated shallowing the lake. The lack of diatoms and the appearance of Cyperaceae and Pteridophyte indicated the expose of lake shore and swampy dryland in $30,840-11,930 \mathrm{yr}$ BP. The appearance diatoms again with the dominance species of $F$. pinnata and Cymbella cistula in the upper $\mathrm{CP}-1$, indicated a swamp to shallow lake with abundant of aquatic vegetation. The succession from $A$. granulata dominant into $F$. tenera reflected a decrease of water depth about 1-2 m. In the late Holocene (1,500 yr BP until present), a succession from $C$. cistula to aerophylous diatoms of Navicula converacea and $F$. pinnata indicated the transition perennially flooded and swampy alluvial plain (Figure 2). The fluctuation of diatom abundance associated with water depth fluctuations during early Holocene [21].

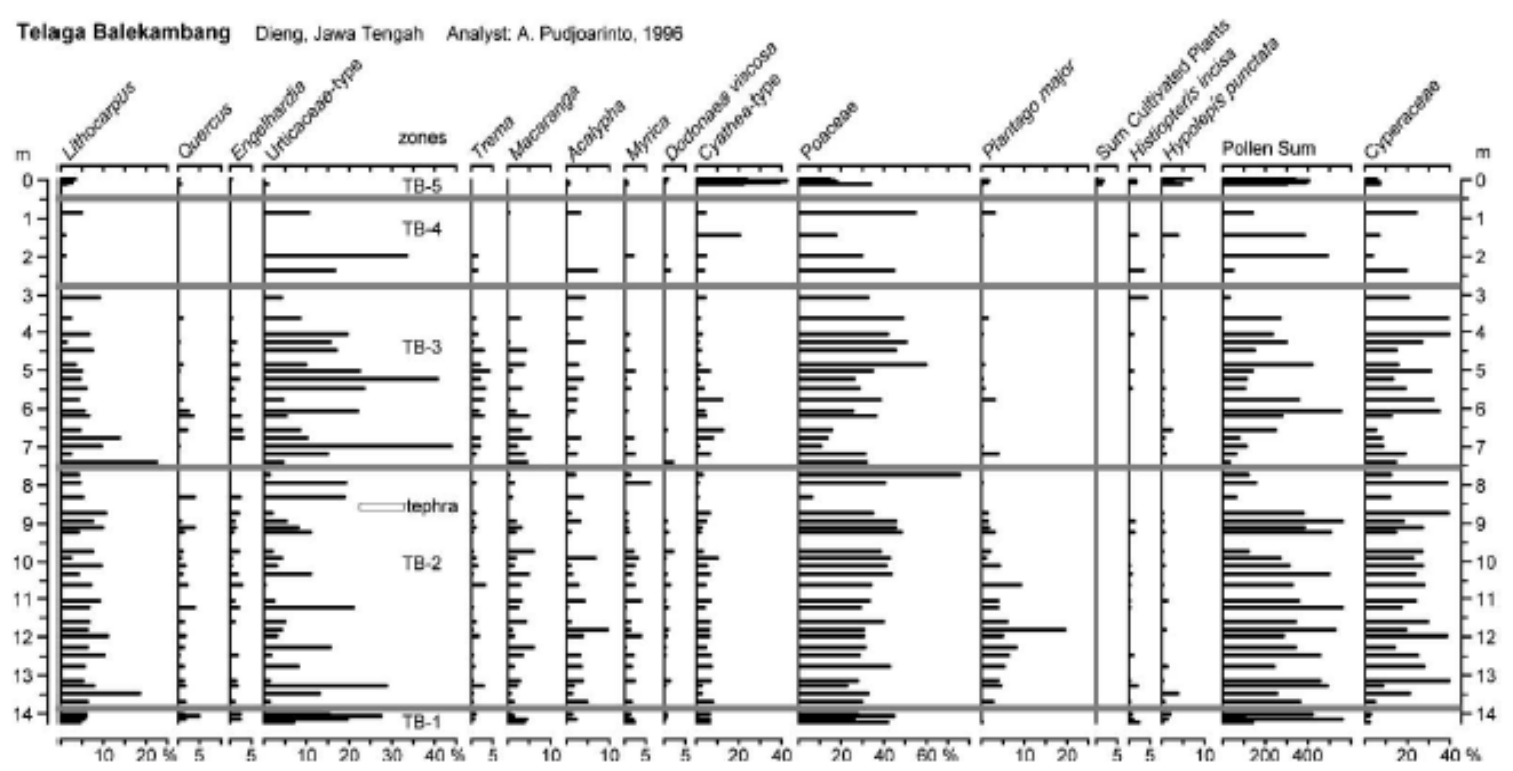

Fig. 1. Pollen stratigraphy of Telaga Balekambang, Dieng [32]

The reconstruction of past environmental changes in vicinity of Rawapening Lake based on diatoms indicated that eutrophic condition of Rawapening Lake was occurred since 1967, as the longest sediment cores collected in 2008 was $63 \mathrm{~cm}$ (Figure 3). The eutrophic condition was indicated by the dominant of Gomphonema parvulum (Kützing) Kützing, Luticola goeppertiana (Bleisch) Mann, Luticola mutica (Kützing) Mann, Mayamaea (syn:Navicula) atomus (Kützing) Lange-Bertalot, Nitzschia palea (Kützing) W.Smith and Nitzschia umbonata (Ehrenberg) LangeBertalot. By the time, there were a shift dominant species into $A$. ambigua (Grunow) Simonsen, A.granulata (Ehrenberg) Simonsen and $U$. acus (Kützing) M. Aboel that indicated high $\mathrm{pH}$ and hypereutrofic condition [34]. Based on monitoring data on $\mathrm{pH}$, indeed the $\mathrm{pH}$ was tend to increase $[34,35]$.

In this paper, the heavy metals of $\mathrm{Ni}, \mathrm{Mg}$ and $\mathrm{B}$ from one coring of Telaga Pengilon showed that stratigraphically, there were trend of increasing $\mathrm{Ni}, \mathrm{Mg}$ and $\mathrm{B}$ form the bottom core $(44 \mathrm{~cm})$ to the top soil $(0$ $\mathrm{cm})$ with the similar trend. The highest concentration of $\mathrm{Ni}$ was in 4-6 cm, Mg was in 14-16 cm, and B was in 22-24 cm. Seems that the layer of 22-24 cm recorded a sharply increase concentration compare to the layers before (Figure 4). The trace element composition and distribution are the net result of processes in the catchment area (allochthonous influences) and in the lake itself (autochthonous influences) can be observed using traced elements. A concentration of B was reported from July 1994 and July 1999 by van Bergen et al, [36]. Ni, Mg, and B in the southeast part of Telaga Pengilon which mainly derived from rock weathering and other geochemical processes. Ni together with $\mathrm{Cu}$ and $\mathrm{Cr}$ of Aibi Lake, Northwest China were derived from geological process, whereas $\mathrm{Cd}, \mathrm{Pb}, \mathrm{Hg}$, and $\mathrm{Zn}$ in the sediment were mainly from pollution [37]. The concentration of $\mathrm{Pb}, \mathrm{Cd}, \mathrm{Cr}$, and $\mathrm{Cu}$ in Telaga Warna Dieng were exceeding the Indonesian water quality standard [38]. Telaga Warna and Telaga Pengilon are connected but the $\mathrm{pH}$ were very differ along with different depth. 

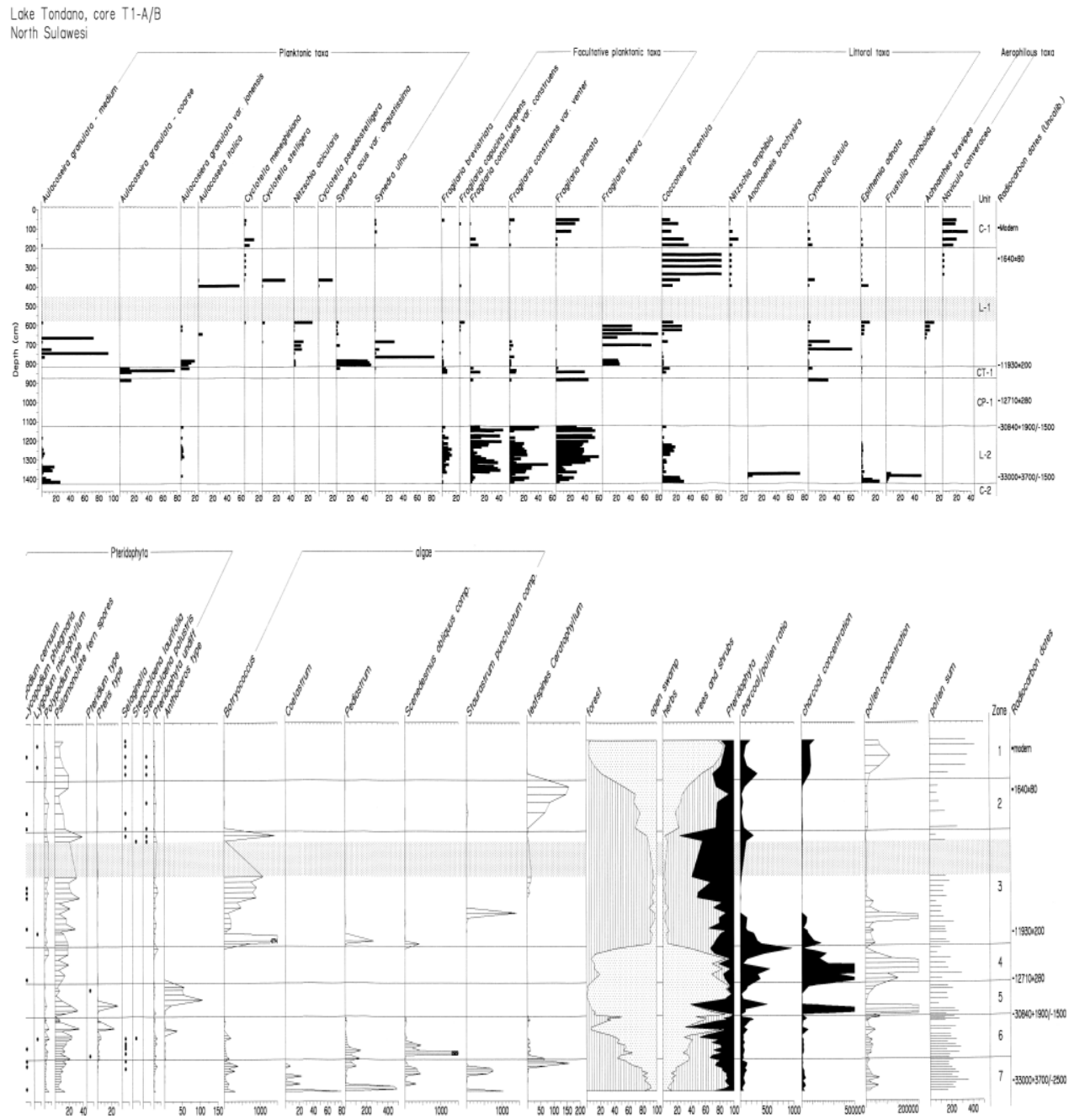

Lake Tondano, core T-1A/B, Summary Diagram

North Sulawesi
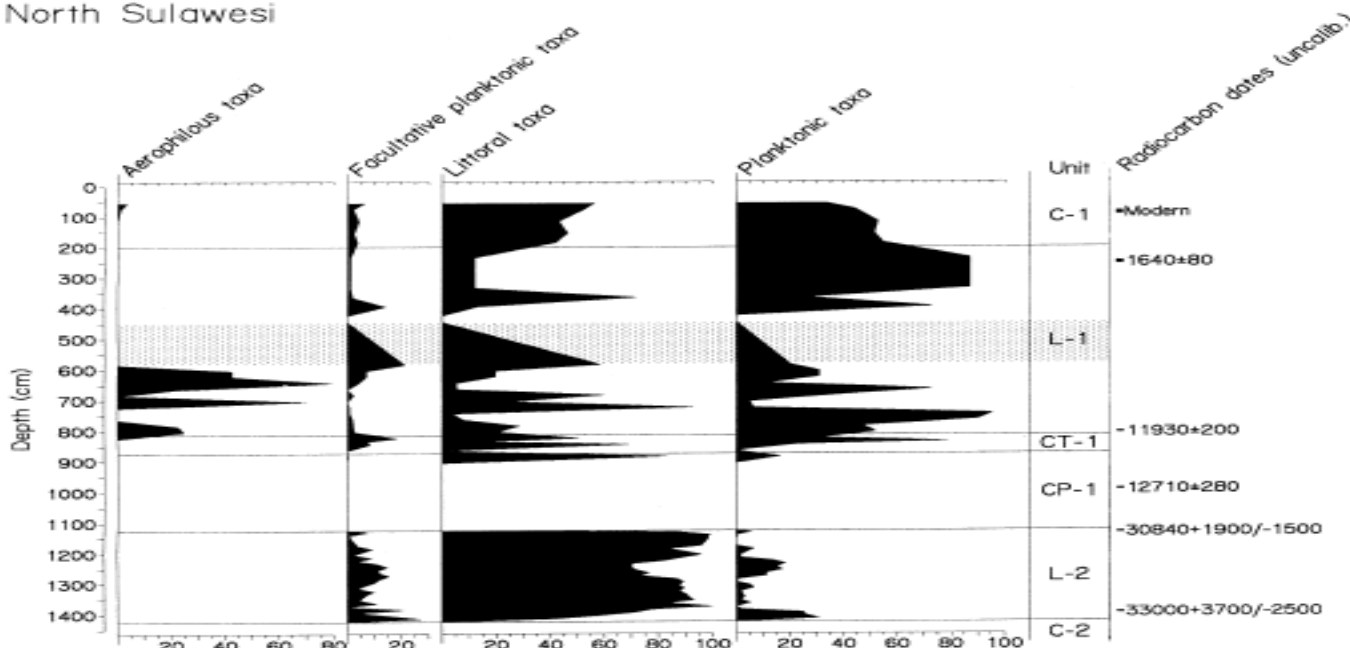

Fig. 2. Changes of diatoms and pollen assemblages in Lake Tondano [21]

Based on the sediment core profile of tracer elements from Lake Kutubu Papua New Guinea, shown that oil/gas extraction activites are significantly increase the concentration of tracer elements in the lakes as well as intensification of human inhabitants in the catchment area [39]. The occurence of tephras in Lake Kutubu marked the timing of climate change, the rate of vegetation change and development of agricultural in Lake Kutubu, that all related to human impact on Lake Kutubu [40]. 

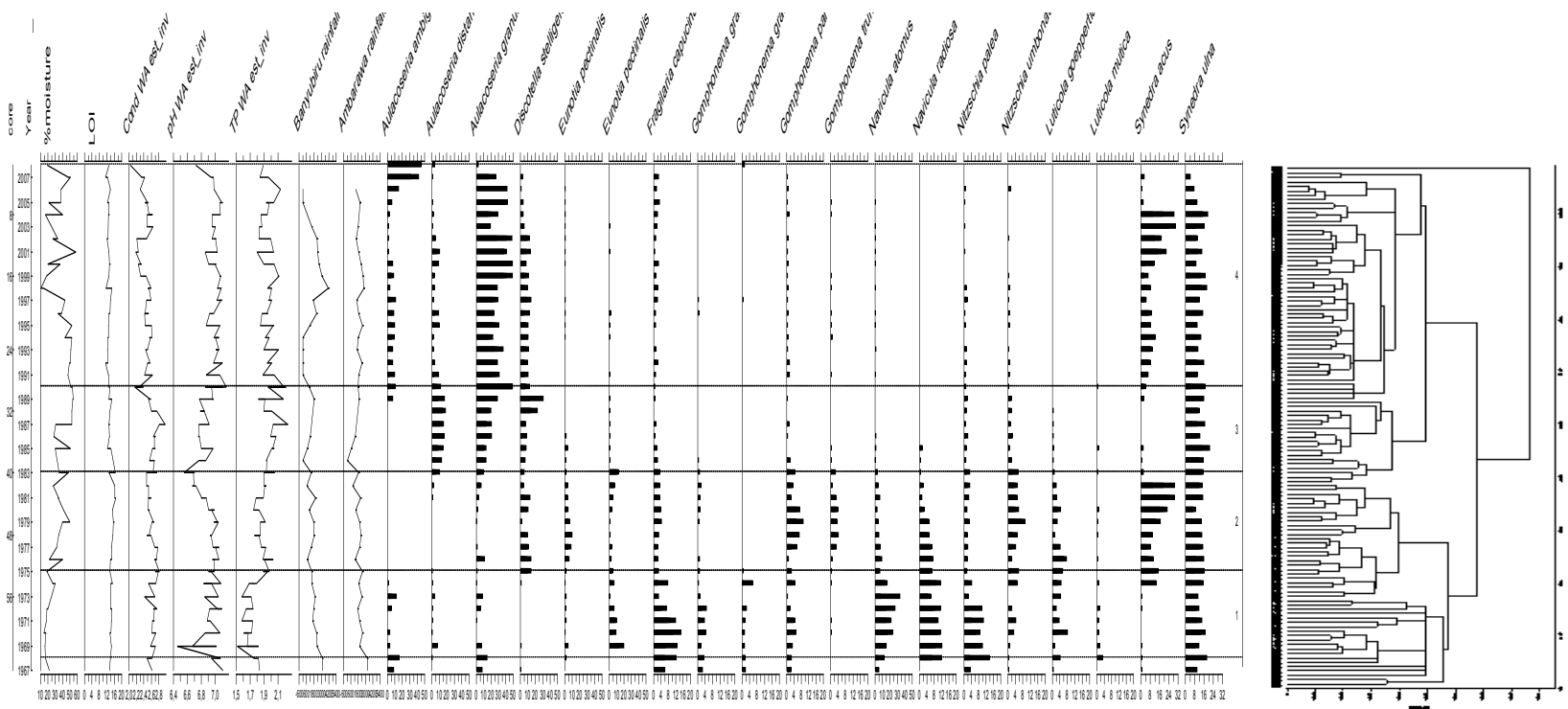

Fig. 3. Diatom stratigraphy of Asinan site from Rawapening Lake, Java and 4 zones [23]

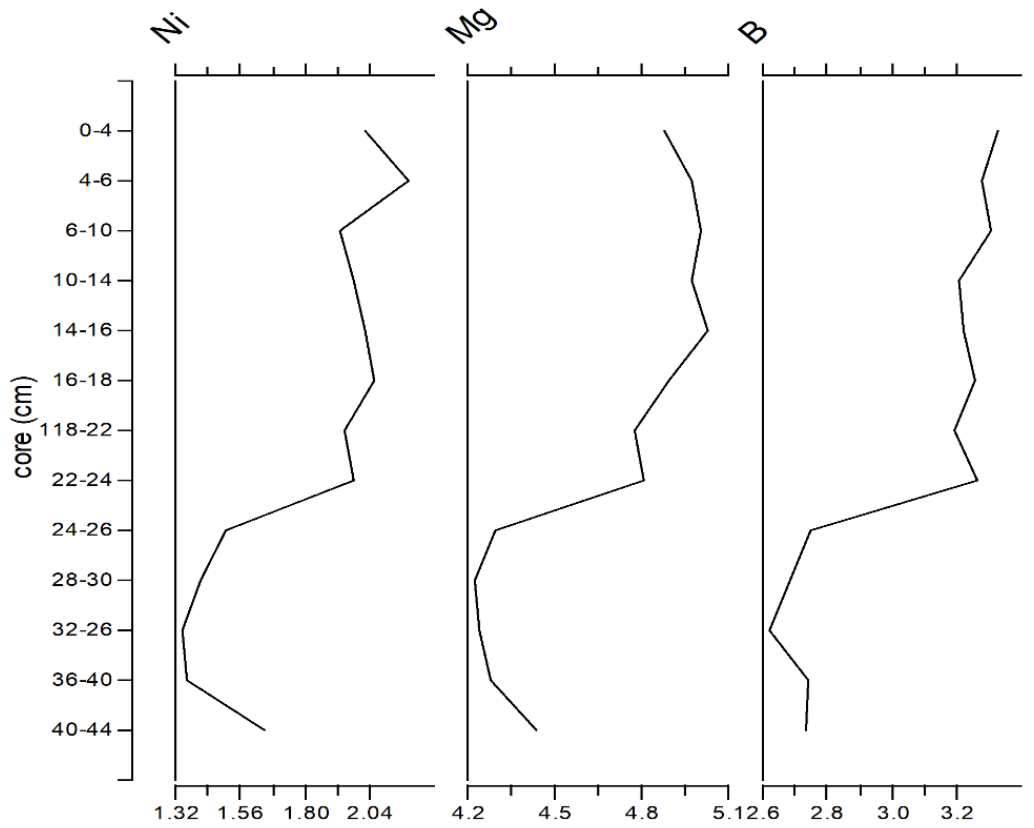

Fig. 4. The stratigraphy of heavy metals of $\mathrm{Ni}, \mathrm{Mg}$, and B from $44 \mathrm{~cm}$ sediment core from Telaga Pengilon and Dieng

\section{CONCLUSION}

Indonesia rich with unique and specific characters of tropical lakes that currently degradate at the accelerating rate due to changes in land use pattern, that affected lakes function and services. Paleolimnology provide significantly information about past environmental change both naturally or human activites in the lakes or cathment area, therefore, provide information to develop suitable environmental management. It is certainly a challanging task to develop paleolimnology in Indonesia to reach the sustainable lakes in the future.

\section{AKNOWLEDGMENT}

This article was produced as a part of project supported by Diponegoro University Indonesia through an International Publication Research Grant Number: 27639/UN7.5.1/PG/2017, 30 March 2017. A heartfelt thanks go to Kenanga Sari, Geyga, Alam Lazuardi, and M Hadi El Amin for field work and diatom analysis. Thanks also go Global Innovation Initiative Project that provides opportunity for Kenanga Sari to analyze heavy metals in Western Carolina University USA supervised by Jerry Miller. 


\section{References}

1. MEF (Ministry of Environment and Forestry). The grand design of Indonesian lakes conservation and rehabititation. Ministry of Environment and Forestry, p.94(2016).

2. ME (Ministry of Environment). Gerakan Penyelamatan Danau (Germadan) Rawapening. Ministry of Enviroment. p.67 (2011).

3. Wetzel RG.. Limn ology: lakes and river ecosystems. Academic Press. 1006 (2001)

4. A.S. Cohen. Paleolimnology: the history and evolution of lake systems. Oxford University Press, NY. P. 525 (2003)

5. J.P. Smol. Pollution of Lakes and Rivers A Paleoenvironmental Perspective. 2nd Ed. Blackwell Publishing, USA(2008)

6. I.R.Tobler. Using Paleolimnology for Lake Restoration and Management. Frontier in Ecology and Evolution (2016)

7. E.S.Talbot Paleolimnology as a Tool to Achieve Environmental Sustainability in the Anthropocene: An Overview. Geoscience (2016).

8. P.E. Hehanusa and G.S. Haryani. Klasifikasi morfogenesis danau di Indonesia untuk mitigasi dampak perubahan iklim. Makalah disampaikan dalam Konferensi Nasional Danau Indonesia I, Sanur-Denpasar-Bali, 13-15 Agustus 2009

9. S. Juggins. The European Diatom Database User Guide Version 1.7.7. University of New Castle, New Castle, UK (2016).

10. F.Ruttner. Arch. Hydobiol. Suppl. 8, 197-454 (1931)..

11. P. Lehmusluoto, B. Machbub, N. Terangna, S. Rusmiputro, F. Achmad, L. Boer, S.S. Brahamana, B. Priadi, B. Setiadji, O. Sayuman and A. Margana. National inventory of the major lakes and reservoirs in Indonesia. Edita Oy Helsinki 72 $\mathrm{pp}(1992)$

12. M. Morlock, H.Vogel, V. Nigg, A. Hasberg, M. Melles, J.M. Russel, S. Bijaskana, and TDP science team. 2016. Geochemical characterization of Lake Towuti, Indonesia: setting the stage for climate reconstructions over several glacialinterglacial cycles. $14^{\text {th }}$ Swiss Geoscience Meeting, Geneva 2016.

13. K.M. Costa, J.M.Russell, H. Vogel, and S. Bijaksana. Palaeogeography, Palaeoclimatology, Palaeoecology 417 467-475(2015).

14. J.M. Russell, H. Vogel, B.L. Konecky, S. Bijaksana, Y. Huang, M. Melles, N. Wattrus, K. Costa, and J.W.King. B.P. 111(14), 51005105(2014).

15. J.Russell and S. Bijaksana. The Towuti Drilling Project: Paleoenvironments, Biological Evolution, and Geomorphology of a Tropical Pacific Lake. Scientific Drilling, No. 14, September 2012.

16. C. Jones, S.A. Crowe, A. Sturn, K.L. Leslie, LCW Maclean, S. Katsev, C. Henny, D.A. Fowle, and
D.E.Canfield. Biogeosciences, 8, 29772991(2011)

17. J.J. Vaillant, G.D.Haffner, and M.E.Cristescu. Integrative and Comparative Biology 51(4), 634643(2011)

18. G. Tamuntuan, S. Bijaksana, E.Gaffar, J. Russell, L.O.Safiuddin, and E. Huliselan E. ITB J. Sci. 42 A (1), 31-48(2010)

19. SA Crowe, AH O’Neill, S Katsev, P Hehanusa, GD Haffner, B Sundby, A Mucci, and DA Fowle. Limnol. Oceanogr. 53(1): 319-331(2008)

20. SE Engelhart, BP Horton, DH Roberts, CL Bryant, and DR Corbett. Marine Geology, 242(1-3): 6581(2007).

21. RAC Dama, J Fluin, P Suparan, and S van der Kaars. Palaeogeography, Palaeoclimatology, Palaeoecology 171: 147-183(2001)

22. JR Rodysill, JM Russell, S Bijaksana, ET Brown, LO Safiuddin, and $\mathrm{H}$ Eggermont. Journal of Plaeolimnlogy 47(1), 125-139(2012).

23. T.R Soeprobowati. S Hadisusanto, P Gell and A. Zawadski. American Journal of Environmental Science (3), 334-344(2012).

24. T.R Soeprobowati, S.W.A Suedy and P Gell. Journal of Coastal Development 15(2), 197 208(2012).

25. H Murwanto, Y Gunnell, S Suharsono, S Sutikno, and F Lavigne. The Holocene 12(3), 459463(2004).

26. PT Setyobudi, PA Suandhi, ZL Tarigan, A Bachtiar, AGR Jayanti, and L Budin. Sedimentology and limnology of Singkarak and Toba Lakes, Sumatra, Indonesia: depositional and petroleum system model for tropical Fluviolacustrine and volcanic related rift basins in Southeast Asia. Proceedings Indonesian Petroleum Association, Forth Annual Convention \& Exhibition May 2016, IPA16-660-G

27. C.A Grand, B.P Horton, H.M Kelsey, C.M Rubin, A.D Hawkes, M.R Daryono, G Rosenberg, S.J Culver. Quaternary Science Reviews 54, 142151(2012).

28. W.A van der Kaars. Palaeogeography, Palaeoclimatology, Palaeoecology. 85: 239-302 (1991).

29. S van der Kaars, X Wang, P Kershaw, F Guichard, and DA Setiabudi. Palaeogeography, Palaeoclimatology, Palaeoecology 155(1-2):135153 (2000).

30. S Nishimura, E Abe, J Nishida, T Yokoyama, A Dharma, P Hehanusa, and F Hehuwat. Techtonophysiscs 109(3-4), 253-261 (1984).

31. RJ.Morley J. Biogeogr. 9, 151-190 (1982)

32. A Pudjoarinto, and EJ Cushing. 2001. Palaeogeography, Palaeoclimatology, Palaeoecology, 171(3-4), 329-340 (2001).

33. E Yulianto, AT Rahardjo, D Noeradi, DA Siregar, and K Hirakawa. 2005. A Holocene Pollen Record of Vegetation and Coastal Environmental 
Changes in the Coastal Swamp Forest at Batulicin, South Kalimantan, Indonesia.

34. T.R Soeprobowati.; S.D Tandjung.; Sutikno; S Hadisusanto.; and P Gell. Biotropia 23(2): 96-104 (2016).

35. T.R Soeprobowati, S.D Tandjung, Sutikno, S Hadisusanto, P Gell. H Hadiyanto and S. W. A Suedy. Biodiversitas 17(2), 657-664(2016).

36. van Bergen MJ, Bernard A, Sumarti S, Sriwana T, and Sitorus K. 2000. Crater lakes of Java: Dieng, Kelutd, and Ijen. Excursion Guidebook, IAVCEI General Assembly, Bali 2000.

37. J Abuduwaili, ZY Zhang, FQ Jiang. PLoS ONE 10(3): e0120001(2015).

38. T.R Soeprobowati.; S.W.A Suedy.; and H. Hadiyanto. IOP Conf. Series: Earth and Environmental Science 55 (2017): 012051 (2017).
39. L Schneider, SG Haberle, WA Maher, F Krikowa, A Zawatdzki, and H Heijnis. Chemosphere 148, 369e379 (2016)

40. L Schneider, B Alloway, , JR Blong, GS Hope, SJ Fallon, FC Pain, WA Maher, and SG Haberle. Journal of Quetanary Science 1-13(2017)

41. TA Goudge, JM Russell, JF Mustard, JW Head, and S Bijaksana. GSA Bulletin 129 (7-8) (2017).

42. LE Becking. 2012. Marine lakes of Indonesia. Naturalis Biodiversity Center, Faculty of Science, Leiden University

43. $\mathrm{S}$ van der Kaars, MAJ Williams, F Bassinot, F Guichard, E Moreno, F Dewilde, and EJ Cook. Quaternary International, 258, 45-53(2012)

44. GB Pasternack and JC Varekamp. Geochemical journal 28, 243-262(1994) 